\title{
A Case of Adenomyomatous Hyperplasia of the Extrahepatic Bile Duct
}

\author{
Masakatsu Numata ${ }^{a}$ Soichiro Morinaga ${ }^{a}$ \\ Takuo Watanabe $^{\text {a }}$ Hiroshi Tamagawa ${ }^{a}$ Naoto Yamamoto ${ }^{a}$ \\ Manabu Shiozawa ${ }^{a}$ Yoichi Kameda $^{\mathrm{b}}$ Shinichi Ohkawac \\ Yasushi Rino $^{d}$ Makoto Akaike ${ }^{a}$ Munetaka Masuda ${ }^{d}$ \\ Departments of a Hepatobiliary and Pancreatic Surgery, bPathology and \\ 'Hepatobiliary and Pancreatic Medicine, Kanagawa Cancer Center, Yokohama, \\ and ${ }^{\mathrm{d} D e p a r t m e n t}$ of Surgery, Yokohama City University, Yokohama, Japan
}

\section{Key Words}

Adenomyomatous hyperplasia - Extrahepatic bile duct · Benign tumor

\begin{abstract}
Adenomyomatous hyperplasia is rarely found in the extrahepatic bile duct. A 54-year-old man was referred to our center with a diagnosis of extrahepatic bile duct stenosis which had been detected by endoscopic retrograde choloangiopancreatography. Abdominal computed tomography revealed thickening of the wall of the middle extrahepatic bile duct, however no malignant cells were detected by cytology. Since bile duct carcinoma could not be ruled out, we performed resection of the extrahepatic duct accompanied by lymph node dissection. Histopathologically, the lesion was diagnosed as adenomyomatous hyperplasia of the extrahepatic bile duct. Present and previously reported cases showed the difficulty of making a diagnosis of adenomyomatous hyperplasia of the extrahepatic bile duct preoperatively or intraoperatively. Therefore, when adenomyomatous hyperplasia is suspected, a radical surgical procedure according to malignant disease may be necessary for definitive diagnosis.
\end{abstract}

\section{Introduction}

Adenomyomatous hyperplasia is considered to be a non-neoplastic, tumor-like, inflammatory lesion which commonly develops in the gallbladder. Benign tumors of the extrahepatic bile duct, including adenomyomatous hyperplasia, are rarely found in clinical practice. Therefore, the etiology of adenomyomatous hyperplasia of the 
extrahepatic bile duct has not been clarified. Its clinical importance lies in its potential to cause symptomatic biliary tract obstruction or cholangitis and its propensity to be confused with malignant lesions, thereby leading to extensive surgical resection. There are no useful diagnostic methods except histologic examination that can be used to distinguish adenomyomatous hyperplasia from malignant tumor. We present a resected case of symptomatic adenomyomatous hyperplasia of the extrahepatic bile duct and review the published reports of adenomyomatous hyperplasia of the extrahepatic bile duct to discuss the diagnostic and clinical relevance of this case.

\section{Case Report}

The patient, a 54-year-old man, was admitted to our hospital with a chief complaint of jaundice. Nothing special was found in physical examination except for icteric change. Laboratory studies revealed aspartate aminotransferase $189 \mathrm{U} / \mathrm{l}$, alanine aminotransferase $779 \mathrm{U} / \mathrm{l}$, alkaline phosphatase $1,766 \mathrm{U} / \mathrm{l}$, total bilirubin $7.9 \mu \mathrm{mol} / \mathrm{l}$, carcinoembryonic antigen $0.8 \mathrm{ng} / \mathrm{ml}$, and carbohydrate antigen 19-9 306.2 U/ml. Endoscopic retrograde choloangiopancreatography (ERCP) showed stenosis of the middle bile duct and slight distention of the upper and intrahepatic bile duct above the stenosis (fig. 1). Abdominal ultrasonography revealed a dilatation of the upper common bile duct to $9 \mathrm{~mm}$ in diameter. Computed tomography detected thickening of the wall in the middle hepatic duct. Neither bile cytology nor brush cytology showed any malignant cells (class I and III). Since bile duct cancer could not be ruled out, extrahepatic bile duct resection accompanied by lymph node dissection was performed. Gross observation of the cut surface showed a white-colored, thickening lesion $20 \times 15 \mathrm{~mm}$ in size (fig. 2). Pathological examination demonstrated that multiple hyperplastic glands without cellular atypia were present in the middle bile duct wall, along with proliferation of both epithelial and smooth muscle components and infiltration by inflammatory cells (fig. 3 ). The patient has been well without any evidence of recurrence for 3 years since his operation.

\section{Discussion}

Benign tumors of the extrahepatic bile duct are rare, and many are malignant [1]. Among benign tumors, adenomyomatous hyperplasia of the extrahepatic duct bile duct is extremely rare, while adenomyomatous hyperplasia is most commonly found in the stomach, gallbladder, duodenum, and jejunum [2]. Microscopically, adenomyomatous hyperplasia is characterized by proliferation of both epithelial and smooth muscle components, and involvement may extend to the serosa [3]. The surrounding glands usually are dilated cystically and filled with mucus, and there is minimal infiltration by chronic inflammatory cells in the stroma in most cases [4]. The microscopic appearance is similar to that of a lesion of the gallbladder known as adenomyomatous hyperplasia [1].

Table 1 shows the reported cases of adenomyomatous hyperplasia of the extrahepatic bile duct. In total, 13 cases have been reported previously [1-3,5-14]. Of these, 2 were men and 11 were women. Mean age was 59.9 years (range 31-82 years). The location of the lesion was upper bile duct in 3 cases, middle in 5 cases, and lower in 5 cases. The most frequent chief complaint was abdominal pain (46.1\%), followed by no complaint (30.7\%).

It is difficult to diagnose adenomyomatous hyperplasia of the extrahepatic bile duct preoperatively or intraoperatively. In fact, the precise preoperative or intraoperative diagnosis could not be given in all previously reported cases, except one that was diagnosed as adenoma by ERCP biopsy. Adenomyomatous hyperplasia of the extrahepatic bile duct is usually diagnosed by histopathologic examination after surgery, 
and previous reports indicate that there is no useful imaging technique to distinguish this lesion from cancer [14]. Consequently, this leads patients to undergo radical resection and not conservative resection. Of the reported cases, 5 were treated by pancreatoduodenectomy and 8 by resection of the extrahepatic bile duct. In our case, we performed resection of the extrahepatic bile duct accompanied by radical lymph node resection, according to operative procedure for bile duct cancer.

Adenomyomatous hyperplasia is thought to be a benign lesion, however previous reports revealed that there is a possibility of malignant transformation of adenomyomatous hyperplasia of various organ, or of recurrence in insufficiently resected cases [1,6]. Iwaki et al. pointed out the risk of making a diagnosis of adenomyomatous hyperplasia based on findings of preoperative biopsy alone and suggested the necessity of performing radical surgery to make a definitive diagnosis [1].

In conclusion, adenomyomatous hyperplasia of the extrahepatic bile duct has to be taken into consideration when treating patients with bile duct stenosis. Preoperative endoscopic and radiological evaluations and intraoperative section biopsies are insufficient for differentiating adenomyomatous hyperplasia from other malignant tumors. Thus, radical surgical procedure and histological confirmation by surgical specimen is needed for a definitive diagnosis and local control when adenomyomatous hyperplasia is suspected. 


\begin{tabular}{|c|c|c|c|}
\hline $\begin{array}{r}\text { Case Reports in } \\
\text { Gastroenterolooy }\end{array}$ & $\begin{array}{l}\text { Case Rep Gastroenterol 2011;5:457-462 } \\
\text { DOI: } 10.1159 / 000331052\end{array}$ & $\begin{array}{l}\text { Published online: } \\
\text { August 22, } 2011\end{array}$ & $\begin{array}{l}\text { () } 2011 \text { S. Karger AG, Basel } \\
\text { ISSN } 1662-0631 \\
\text { www.karger.com/crg }\end{array}$ \\
\hline
\end{tabular}

Table 1. Reported cases of adenomyomatous hyperplasia of the extrahepatic bile duct

\begin{tabular}{|c|c|c|c|c|c|c|}
\hline First author, year & Sex & Age & $\begin{array}{l}\text { Location } \\
\text { in bile duct }\end{array}$ & Chief complaint & $\begin{array}{l}\text { Pathologic diagnosis } \\
\text { before surgery }\end{array}$ & Treatment \\
\hline Dowdy (1962) & $\mathrm{F}$ & 38 & middle & jaundice & not performed & resection of EHBD \\
\hline Burhans (1971) & $\mathrm{F}$ & 62 & upper & weight loss & not performed & resection of EHBD \\
\hline Cook (1988) & $\mathrm{F}$ & 82 & middle & abdominal pain & not performed & resection of EHBD \\
\hline Ikei (1989) & M & 52 & lower & abdominal pain & not performed & $\mathrm{PD}$ \\
\hline Legakis (1990) & $\mathrm{F}$ & 55 & middle & abdominal pain & not performed & resection of EHBD \\
\hline Matsumoto (1992) & M & 75 & lower & not described & not described & $\mathrm{PD}$ \\
\hline Imai (1995) & $\mathrm{F}$ & 54 & upper & none & not performed & resection of EHBD with LND \\
\hline Lauffer (1998) & $\mathrm{F}$ & 69 & middle & none & adenoma by ERCP biopsy & resection of EHBD \\
\hline Tsukamoto (1999) & $\mathrm{F}$ & 31 & middle & abdominal pain & not performed & resection of EHBD \\
\hline Ojima $(2000)$ & $\mathrm{F}$ & 64 & lower & abdominal pain & not performed & $\mathrm{PD}$ \\
\hline Sato $(2000)$ & $\mathrm{F}$ & 64 & upper & none & no malignancy by cytology & resection of EHBD with LND \\
\hline Aoun (2005) & $\mathrm{F}$ & 71 & lower & abdominal pain & no malignancy by cytology & $\mathrm{PD}$ \\
\hline Iwaki (2008) & $\mathrm{F}$ & 62 & lower & none & no malignancy by cytology & PPPD \\
\hline Present case & M & 54 & middle & jaundice & no malignancy by cytology & resection of EHBD with LND \\
\hline
\end{tabular}

EHBD = Extrahepatic bile duct; ERCP = endoscopic retrograde choloangiopancreatography; LND = lymph node dissection; $\mathrm{PD}=$ pancreatoduodenectomy; $\mathrm{PPPD}=$ pylorus-preserving pancreatoduodenectomy.

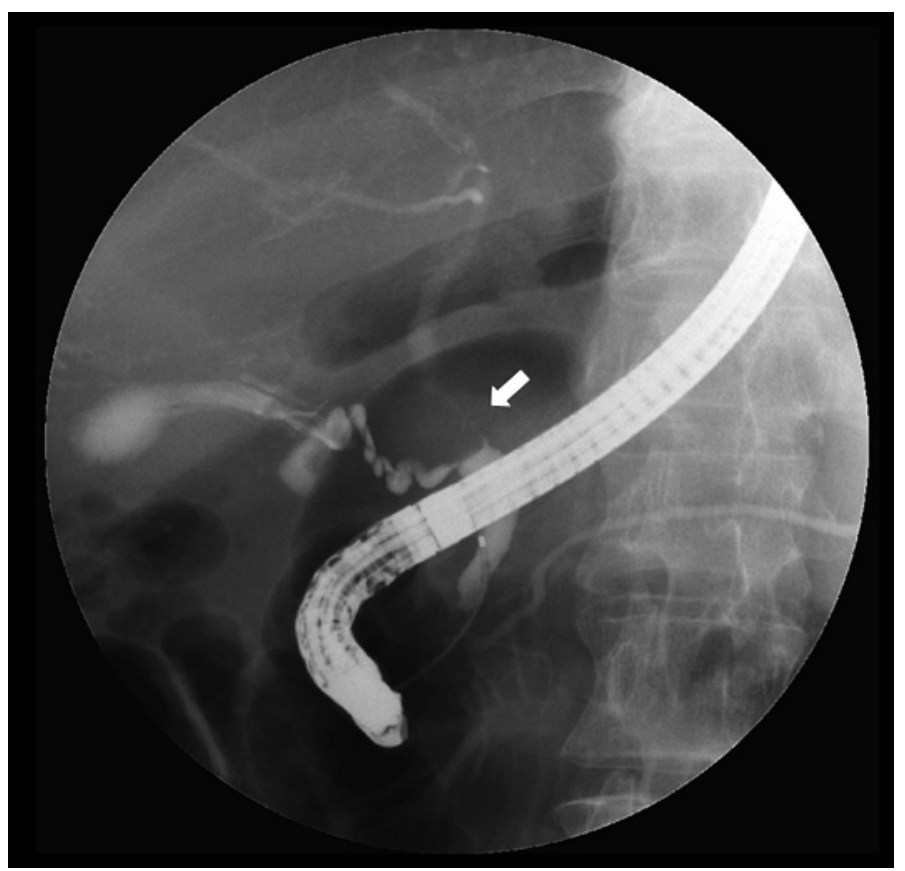

Fig. 1. ERCP showed a 15-mm-long stenosis of the middle bile duct (arrow) and a slight dilatation of the common hepatic bile duct above the stenosis. 


\begin{tabular}{r|l|l|l}
$\begin{array}{r}\text { Case Reports in } \\
\text { Gastroenterology }\end{array}$ & $\begin{array}{l}\text { Case Rep Gastroenterol 2011;5:457-462 } \\
\text { DOl: 10.1159/000331052 }\end{array}$ & $\begin{array}{l}\text { Published online: } \\
\text { August 22, 2011 }\end{array}$ & $\begin{array}{l}\text { O 2011 S. Karger AG, Basel } \\
\text { ISSN 1662-0631 } \\
\text { www.karger.com/crg }\end{array}$ \\
\hline
\end{tabular}

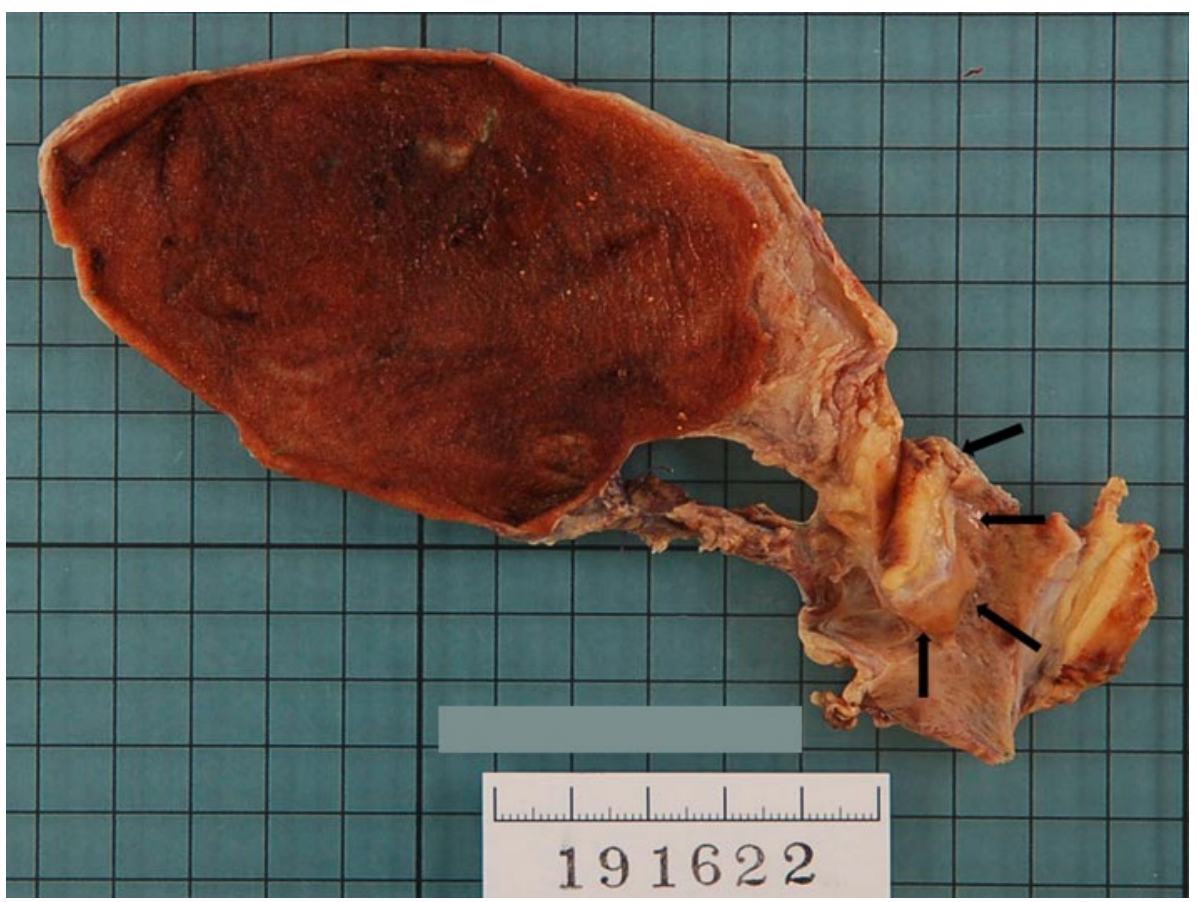

Fig. 2. Gross examination showing a locally hypertrophic lesion in the middle bile duct. The lesion is $15 \times 20 \mathrm{~mm}$ in-size, whitish, and solid (arrows).

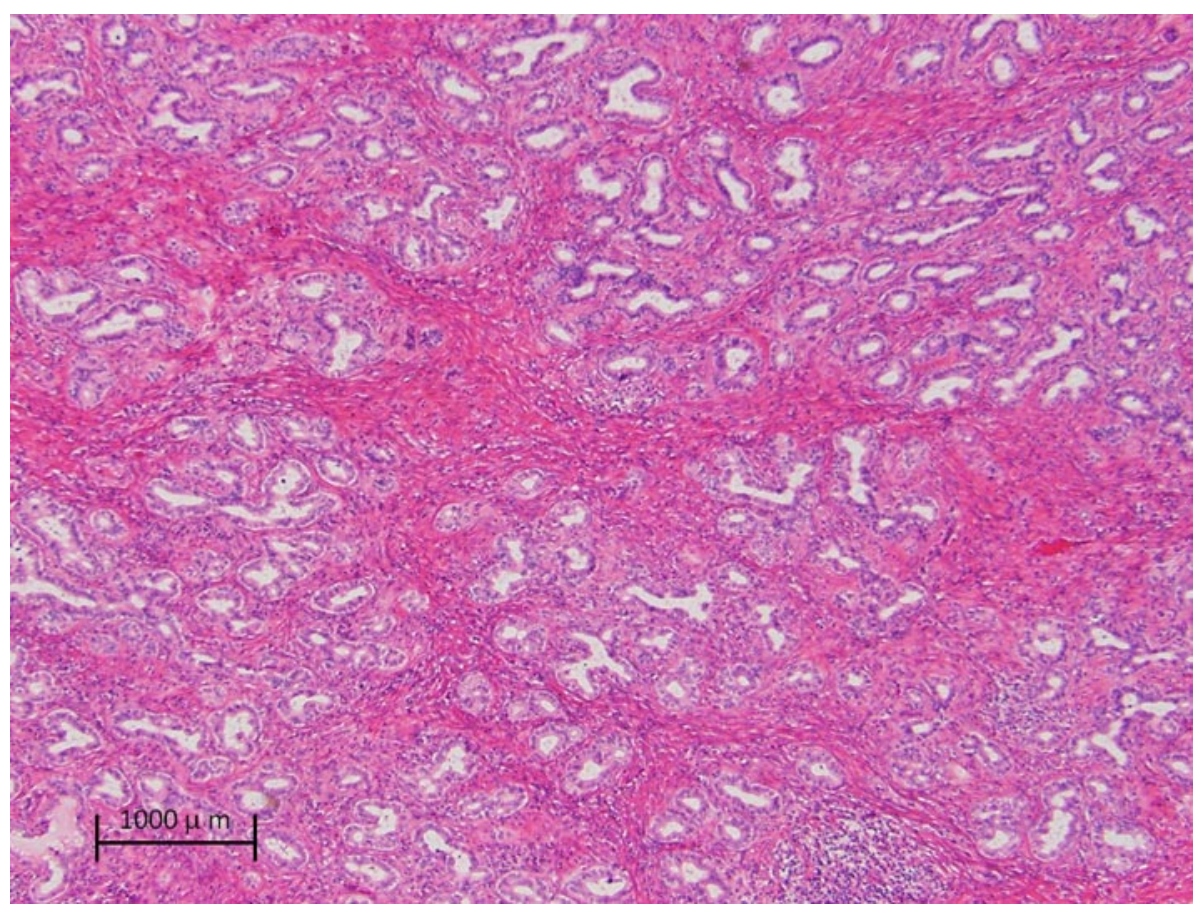

Fig. 3. Histological examination of the resected specimen demonstrated fibrous thickening of the wall in the middle bile duct along with multiple hyperplastic glands with no atypia, proliferation of smooth muscle components, and local infiltration by inflammatory cells $(\mathrm{H} \& \mathrm{E}, \times 40)$. 


\begin{tabular}{|c|c|c|c|}
\hline $\begin{array}{r}\text { Case Reports in } \\
\text { Gastroenterology }\end{array}$ & $\begin{array}{l}\text { Case Rep Gastroenterol 2011;5:457-462 } \\
\text { DOI: } 10.1159 / 000331052\end{array}$ & $\begin{array}{l}\text { Published online: } \\
\text { August 22, } 2011\end{array}$ & $\begin{array}{l}\text { @ } 2011 \text { S. Karger AG, Basel } \\
\text { ISSN 1662-0631 } \\
\text { www.karger.com/crg }\end{array}$ \\
\hline
\end{tabular}

\section{References}

1 Iwaki K, Shibata K, Ohta M, Endo Y, Uchida H, Tominaga M, Okunaga R, Kai S, Kitano S: Adenomyomatous hyperplasia of the common bile duct: Report of a case. Surg Today 2008;38:85-89.

2 Lauffer JM, Baer HU, Maurer CA, Frohling S, Scheurer U, Zimmermann A, Buchler MW: Adenomyoma of the distal common bile duct mimicking cholangiocarcinoma. Dig Dis Sci 1998;43:1200-1204.

- 3 Imai S, Uchiyama S, Suzuki T, Arita A, Yoshida K, Kodama H, Sato T, Akimaru K, Shibuya T, Kameda H: Adenomyoma of the common hepatic duct. J Gastroenterol 1995;30:547-550.

4 Ram MD, Midha D: Adenomyomatosis of the gallbladder. Surgery 1975;78:224-229.

5 Dowdy GS Jr, Olin WG Jr, Shelton EL Jr, Waldron GW: Benign tumors of the extrahepatic bile ducts. Report of three cases and review of the literature. Arch Surg 1962;85:503-513.

6 Burhans R, Myers RT: Benign neoplasms of the extrahepatic biliary ducts. Am Surg 1971;37:161-166.

7 Cook DJ, Salena BJ, Vincic LM: Adenomyoma of the common bile duct. Am J Gastroenterol 1988;83:432-434.

8 Ikei S, Mori K, Yamane T, Katafuchi S, Hirota M, Akagi M: Adenofibromyomatous hyperplasia of the extrahepatic bile duct - a report of two cases. Jpn J Surg 1989;19:576-582.

9 Legakis NC, Stamatiadis AP, Papadimitriou-Karapanou C, Apostolidis NS: Adenomyoma of the common bile duct. Arch Surg 1990;125:543.

10 Matsumoto Y, Fujii H, Miura K, Inoue S, Sekikawa T, Aoyama H, Ohnishi N, Sakai K, Suda K: Successful pancreatojejunal anastomosis for pancreatoduodenectomy. Surg Gynecol Obstet 1992;175:555-562.

-11 Tsukamoto T, Kinoshita H, Hirohashi K, Kubo S, Tanaka H, Hamba H, Shuto T, Yamamoto T: Adenomyoma of the common bile duct. Hepatogastroenterology 1999;46:1627-1630.

12 Ojima H, Takenoshita S, Nagamachi Y: Adenomyoma of the common bile duct: Report of a case. Hepatogastroenterology 2000;47:132-134.

13 Sato Y, Shirai Y, Date K, Iwaya A, Hatakeyama K: Asymptomatic adenomyoma of the common hepatic duct discovered during a medical checkup: Report of a case. Hepatogastroenterology 2000;47:636-638.

14 Aoun N, Zafatayeff S, Smayra T, Haddad-Zebouni S, Tohme C, Ghossain M: Adenomyoma of the ampullary region: Imaging findings in four patients. Abdom Imaging 2005;30:86-89. 